OPEN ACCESS

Edited by:

Adrian John Frederick Luty, Institut de Recherche Pour le Développement (IRD), France

Reviewed by:

Sandrine Houze,

Université Paris Descartes, France

Carlos Robello,

Universidad de la República, Uruguay

${ }^{*}$ Correspondence: Margarida Borges mborges@ff.up.pt

Specialty section: This article was submitted to Microbial Immunology, a section of the journal

Frontiers in Immunology

Received: 27 October 2020 Accepted: 29 December 2020

Published: 15 February 2021

Citation:

Barros M, Teixeira D, Vilanova $M$, Correia A, Teixeira $N$ and Borges M (2021) Vaccines in Congenital Toxoplasmosis: Advances and Perspectives.

Front. Immunol. 11:621997. doi: 10.3389/fimmu.2020.621997

\section{Vaccines in Congenital Toxoplasmosis: Advances and Perspectives}

\author{
Mariana Barros ${ }^{1}$, Daniela Teixeira ${ }^{1}$, Manuel Vilanova ${ }^{2,3,4}$, Alexandra Correia ${ }^{2,3,4}$, Natercia \\ Teixeira $^{5}$ and Margarida Borges ${ }^{5 *}$
}

${ }^{1}$ Departamento de Ciências Biológicas, Faculdade de Farmácia, Universidade do Porto, Porto, Portugal, 2 Immunobiology Group, Instituto de Investigação e Inovação em Saúde (i3S), Universidade do Porto, Porto, Portugal, ${ }^{3}$ Instituto de Biologia Molecular e Celular (IBMC), Universidade do Porto, Porto, Portugal, ${ }^{4}$ Departamento de Imuno-Fisiologia e Farmacologia, Instituto de Ciências Biomédicas Abel Salazar (ICBAS), Universidade do Porto, Porto, Portugal, ${ }^{5}$ Applied Molecular Biosciences Unit/Rede de Química e Tecnologia (UCIBIO/REQUIMTE), Departamento de Ciências Biológicas, Faculdade de Farmácia, Universidade do Porto, Porto, Portugal

Congenital toxoplasmosis has a high impact on human disease worldwide, inducing serious consequences from fetus to adulthood. Despite this, there are currently no human vaccines available to prevent this infection. Most vaccination studies against Toxoplasma gondii infection used animal models in which the infection was established by exogenous inoculation. Here, we review recent research on potential $T$. gondii vaccines using animal models in which infection was congenitally established. Endeavors in this field have so far revealed that live or subunit vaccines previously found to confer protection against extrinsically established infections can also protect, at least partially, from vertically transmitted infection. Nevertheless, there is no consensus on the more adequate immune response to protect the host and the fetus in congenital infection. Most of the vaccination studies rely on the assessment of maternal systemic immune responses, quantification of parasitic loads in the fetuses, and survival indexes and/or brain parasitic burden in the neonates. More research must be carried out not only to explore new vaccines but also to further study the nature of the elicited immune protection at the maternal-fetal interface. Particularly, the cellular and molecular effector mechanisms at the maternal-fetal interface induced by immunization remain poorly characterized. Deeper knowledge on the immune response at this specific location will certainly help to refine the vaccine-induced immunity and, consequently, to provide the most effective and safest protection against $T$. gondii vertical infection.

Keywords: pregnancy, toxoplasmosis, congenital, vaccination, maternal-fetal

\section{INTRODUCTION}

Toxoplasma gondii is an obligate intracellular protozoan parasite and the etiologic agent of congenital toxoplasmosis. T. gondii is considered one of the most successful parasites worldwide, infecting over $30 \%$ of the human population, with high associated disease burden $(1,2)$. Seroprevalence varies greatly from region to region, ranging from approximately $30 \%$ in the American, European, and Asiatic regions, to more than $60 \%$ in the African continent $(3,4)$. The 
disease is potentially dangerous in women who become infected during pregnancy, as it can lead to transplacental transmission of the parasite upon primary infection or re-infection with highly virulent strains $(5,6)$. The incidence of congenital toxoplasmosis varies according to the timing of infection during pregnancy. The transmission rate is greater in the final stages of pregnancy, but the severity of infection is greater in early gestation (7). In the more severe cases, hydrocephalus, chorioretinitis, and cerebral calcification may occur, according to the parasite's brain and ocular tropism (5). An association between congenital infection and the development of neurological and psychiatric disorders later in life, including schizophrenia, Alzheimer's disease, bipolar disease, and even suicidal tendencies has also been suggested $(8,9)$.

Innate and adaptive immunity determines protection against T. gondii infection. An effective immune response must control parasite growth while avoiding immunopathology. In both mice and humans, the IL-12- IFN- $\gamma$ axis is the main immune mechanism responsible for parasite control. Protection mediated by IFN- $\gamma$ produced by NK and Th1 cells induces the expression of immunity-related GTPase and/or guanylatebinding proteins, indoleamine-2,3-dioxygenase, and NO production. TNF- $\alpha$ has also been associated with host protection, as highlighted in patients with defective IFN- $\gamma$ signaling (10). TGF- $\beta$, IL- 6 , and IL-23 promote the production of IL-17 that may also play a host protective role in toxoplasmosis by avoiding excessive IFN- $\boldsymbol{\gamma}$-dependent inflammation (11). T cells producing IL-10, which include $\mathrm{T}$ regulatory cells and Foxp $3^{-}$T-bet $^{+}$Th1 cells, can limit excessive inflammation driven by $T$. gondii (12). A regulatory role for IL-4, and IL-27 in minimizing host tissue injury due to exacerbated inflammation has also been shown $(10,13)$. A good vaccine candidate would thus induce not only IL-12 and IFN- $\gamma$, but also counterbalancing cytokines such as IL-4, IL-10, and IL-27 (14).

It is important to note that there are no licensed human vaccines able to prevent toxoplasmosis (15). The lack of effective treatment makes the development of a vaccine against congenital toxoplasmosis one of the main objectives in the management of this disease. Here, recent findings in vaccination approaches to congenital toxoplasmosis using animal models of vertical $T$. gondii infection will be reviewed and the possible implications in the quest for a vaccine protecting from congenital toxoplasmosis will be discussed.

\section{IN VIVO MODELS TO STUDY CONGENITAL INFECTION}

In the study of toxoplasmosis, animal models are used to better understand the disease pathology and the immunological mechanisms induced by infection, as well as to assess the effectiveness of experimental vaccination. However, no single animal model has, so far, been able to mimic all clinical symptoms and signs developed by humans in response to $T$. gondii infection (16). For congenital toxoplasmosis, the murine model is commonly used as it allows a short pregnancy period and mimics features of human congenital toxoplasmosis, namely the co-localization of inflammatory cells and necrosis at the maternal-fetal interface after primo-infection during pregnancy (17). Further, primo-infection confers resistance to maternal fetal transmission throughout later infections (16). However, the immune response to $T$. gondii in mice and humans presents distinct features and this should be adequately considered $(18,19)$.

Most vaccination studies in congenital infection reviewed here used Kunming, BALB/c, Swiss OF1, and CBA/J mice. No study was found using the $\mathrm{C} 57 \mathrm{BL} / 6$ mouse strain. This might be due to excessive susceptibility to disease exhibited by $T$. gondii infected $\mathrm{C} 57 \mathrm{BL} / 6$ mice. In contrast, $\mathrm{BALB} / \mathrm{c}$ mice present higher resistance to infection, more closely resembling humans, rendering this strain more suitable for vaccination studies in congenital infection models (20-22). In murine congenital toxoplasmosis, $\mathrm{C} 57 \mathrm{BL} / 6$ mice exhibited higher abortion rate compared to $\mathrm{BALB} / \mathrm{c}$ due to exacerbated proinflammatory cytokines such as TNF- $\alpha$ (23). Mouse strain differences in major histocompatibility complex haplotypes (e.g., $\mathrm{H}-2^{\mathrm{b}}, \mathrm{H}-2^{\mathrm{d}}, \mathrm{H}-2^{\mathrm{k}}$ for $\mathrm{C} 57 \mathrm{BL} / 6, \mathrm{BALB} / \mathrm{c}$, and $\mathrm{CBA} / \mathrm{J}$, respectively), and therefore, antigenic presentation, could explain different susceptibility to T. gondii infection and induced immunopathology (20).

Other animal models can be used such as sheep, rats, guinea pig, or hamster (24-28). Rats and sheep are widely used in studies addressing drug effectiveness to T. gondii (18). Rats have placental development and hemochorial placentation identical to humans (29). In sheep, congenital toxoplasmosis is very similar to what occurs in humans (15). Thus, sheep is an adequate animal model to study congenital toxoplasmosis, not only because it shares important aspects with the human infection, but also because it directly contributes to the study of new disease control measures in livestock, also severely affected by $T$. gondii (15). There are well established models of toxoplasmosis in pregnant sheep that provide a starting point for the preparation and testing of new vaccines (15).

\section{VACCINES IN VERTICAL INFECTION}

This section aims to describe the vaccines already tested in congenital infection models, and to reveal the gap of analysis concerning immune cells and related mechanisms induced by immunization at the level of maternal-fetal interface as wells as in the neonates. Literature research was performed through a PubMed search, using the query "[(Toxoplasma gondii) AND (vaccine)] AND (congenital toxoplasmosis [title/abstract])". The results presented pertain to studies using pregnant mice where protection and immune responses of pregnant mice and their offspring was evaluated.

\section{Live-Attenuated Vaccines}

Live-attenuated vaccines have been the most studied in the context of congenital transmission (Table 1). These vaccines consist of parasites with reduced virulence but are nevertheless capable of inducing an immune response (36). Alternatively, 
TABLE 1 | Live-attenuated vaccines tested in vertical Toxoplasma gondii infection models.

\begin{tabular}{|c|c|c|c|c|c|c|c|c|}
\hline Strain/animal & $\begin{array}{l}\text { Immunogen/strain/ } \\
\text { delivery }\end{array}$ & $\begin{array}{l}\text { Day of mating } \\
\text { post- } \\
\text { immunization }\end{array}$ & $\begin{array}{l}\text { ChallengePregnancy } \\
\text { day/route/\#parasite } \\
\text { form/Strain }\end{array}$ & $\begin{array}{c}\text { Dam } \\
\text { sacrifice }\end{array}$ & Maternal parameters & Progeny parameters & Highlighted results & References \\
\hline $\begin{array}{l}\text { Swiss OF1/ } \\
\text { mice }^{*}\end{array}$ & $\begin{array}{l}20 \text { tachyzoites } \Delta \text { mic } 1-3 / \\
\mathrm{RH} / \\
\text { ip }\end{array}$ & Day 60 & $\begin{array}{l}\text { Day } 11 / \text { oral/ } \\
45 \text { cysts/ } \\
76 K \text { strain }\end{array}$ & $\begin{array}{l}\text {-Day } 17 \text { of } \\
\text { pregnancy } \\
\text { (exp\#1) } \\
-1 \text { month } \\
\text { after delivery } \\
\text { (exp\#2) }\end{array}$ & $\begin{array}{l}\text {-Toxoplasma specific lgG } \\
\text { levels } \\
\text {-Ex-vivo splenocyte specific } \\
\text { cytokine production (exp\#1) } \\
\text {-Brain cyst load (exp\#2) }\end{array}$ & $\begin{array}{l}\text {-Fetus parasite load (exp\#1) } \\
\text {-Survival of neonates and } \\
\text { mean weight of pups at day } \\
11 \text { after birth } \\
\text {-Brain cyst load at day } 35 \\
\text { after birth (exp\#2). }\end{array}$ & $\begin{array}{l}\text {-Potent maternal humoral and } \\
\text { Th1 responses. } \\
\text {-Decreased fetus parasite load } \\
\text { and, maternal and neonate } \\
\text { brain parasite load. } \\
-100 \% \text { Neonate survival and } \\
\text { higher pups weight. }\end{array}$ & (30) \\
\hline $\begin{array}{l}\text { Bizet, } \\
\text { Romanov, and } \\
\text { Solognot/ } \\
\text { ewes }^{\star \star}\end{array}$ & $\begin{array}{l}10^{5}(\exp \# 1), 2 \times 10^{6} \\
\text { (exp\#2), and } 10^{5} \text { (exp\#3) } \\
\text { tachyzoites } \Delta \text { mic } 1-3 / \\
\mathrm{RH} / \\
\text { sc (exp\#1, \#2) and ip } \\
\text { (exp\#3) }\end{array}$ & Day 60 & $\begin{array}{l}\text { Day } 75 \text { (mid gestation)/ } \\
\text { oral/ } \\
400 \text { sporulated oocysts } \\
\text { (exp\#1, \#2), } 100 \\
\text { sporulated oocysts } \\
\text { (exp\#3)/ } \\
\text { PRU strain }\end{array}$ & $\begin{array}{l}\text { Day } 135 \text { of } \\
\text { pregnancy } \\
\text { (exp\#1, \#3) }\end{array}$ & $\begin{array}{l}\text {-Seroconversion after } \\
\text { immunization and before } \\
\text { pregnancy (exp\#1, \#2, \#3) } \\
\text {-Evaluation of infection } \\
\text { clinical signs (febrile } \\
\text { response) (exp\#1, \#2, \#3) } \\
\text {-Brain cyst load (exp\#1, 3) }\end{array}$ & $\begin{array}{l}\text {-Number of non-viable and } \\
\text { viable lambs. } \\
\text {-Evaluation of abortion. } \\
\text {-Mean weights of viable } \\
\text { lambs. } \\
\text {-Brain cyst load in lambs. }\end{array}$ & $\begin{array}{l}\text {-Maternal seroconversion and } \\
\text { lower febrile response. } \\
\text {-Protection against } T \text {. gondii } \\
\text { abortion and higher rate of } \\
\text { viable lambs. } \\
\text {-Decreased brain parasite load } \\
\text { in vaccinated ewes and in the } \\
\text { lambs. }\end{array}$ & (31) \\
\hline Kunming/mice & $\begin{array}{l}5 \times 10^{4} \text { tachyzoites } \\
\Delta g r a 17 / \\
\mathrm{RH} / \\
\text { ip }\end{array}$ & Day 70 & $\begin{array}{l}\text {-Day 12/oral/ } \\
10 \text { Cysts/Pru strain } \\
\text { (exp\#1) } \\
\text {-Day 18/ip/ } \\
200 \text { tachyzoites/ } \\
\text { RH strain (exp\#2) }\end{array}$ & $\begin{array}{l}\text {-Day } 18 \text { of } \\
\text { pregnancy } \\
\text { (exp\#1) } \\
\text {-Day } 30 \text { after } \\
\text { delivery } \\
\text { (exp\#2) }\end{array}$ & $\begin{array}{l}\text {-Ex-vivo splenocyte specific } \\
\text { cytokine production (exp\#1) } \\
\text {-Brain cyst load } \\
\text { (exp\#2) }\end{array}$ & $\begin{array}{l}\text {-Litter size and survival of } \\
\text { delivered pups at birth and } 5 \\
\text { days after birth (exp\#2). } \\
\text {-Body weight } 35 \text { days after } \\
\text { birth (exp\#1) and } 5 \text { days after } \\
\text { birth (exp\#2). } \\
\text {-Brain cyst burden in pups at } \\
35 \text { days after birth. }\end{array}$ & $\begin{array}{l}\text {-Higher maternal IFN- } \gamma \text {, IL-12, } \\
\text { and IL-10 productions. } \\
\text {-Decreased maternal brain } \\
\text { parasite load and no clinical } \\
\text { signs in immunized dams. } \\
\text {-Protection against } T \text {. gondii } \\
\text { abortion. } \\
\text {-Higher litter sizes of viable } \\
\text { neonates, survival rate and } \\
\text { body weight. } \\
\text {-Decreased pup brain parasite } \\
\text { load. }\end{array}$ & (32) \\
\hline Kunming/mice & $\begin{array}{l}10^{6} \text { tachyzoites } \\
\Delta \text { gra17 } n p t 1 / \\
\mathrm{RH} / \\
\mathrm{ip}\end{array}$ & Day 60 & $\begin{array}{l}\text { Day 5/oral/ } \\
10 \text { cysts/ } \\
\text { Pru strain }\end{array}$ & $\begin{array}{l}\text { Day } 30 \text { after } \\
\text { delivery }\end{array}$ & Brain cyst load. & $\begin{array}{l}\text {-Litter size and survival rates } \\
\text { of delivered pups at birth and } \\
30 \text { days after birth } \\
\text { - Body weight } 30 \text { days after } \\
\text { birth. } \\
\text {-Brain cysts burden in pups at } \\
30 \text { after birth. }\end{array}$ & $\begin{array}{l}\text {-Decreased maternal brain } \\
\text { parasite load. } \\
\text {-No abortions in immunized } \\
\text { mice. } \\
\text {-Increased litter size, pups } \\
\text { survival rate, and body weight. }\end{array}$ & (33) \\
\hline Kunming/mice & $\begin{array}{l}500 \text { tachyzoites } \Delta c d p k 2 / \\
\text { Pru/ } \\
\text { ip }\end{array}$ & Day 70 & $\begin{array}{l}\text { Day 12/oral/ } \\
10 \text { cysts } \\
\text { /Pru strain }\end{array}$ & $\begin{array}{l}\text {-Day } 18 \text { of } \\
\text { pregnancy } \\
\text { (exp\#1) } \\
\text {-Day } 5 \text { after } \\
\text { delivery } \\
\text { (exp\#2) }\end{array}$ & $\begin{array}{l}\text {-Ex-vivo splenocyte specific } \\
\text { cytokine (exp\#1). } \\
\text {-Brain cyst load } \\
\text { (exp\#2). }\end{array}$ & $\begin{array}{l}\text {-Litter size and survival of } \\
\text { delivered pups at birth and } 35 \\
\text { after birth. } \\
\text { - Body weight } 35 \text { days after } \\
\text { birth. } \\
\text { - Brain cysts burden in pups } \\
\text { at } 35 \text { after birth. }\end{array}$ & $\begin{array}{l}\text {-Higher maternal IFN- } \gamma \text {, IL-2, } \\
\text { IL-12, and IL-10 production. } \\
\text { - Decreased maternal brain } \\
\text { parasite load. } \\
\text { - Higher litter sizes of viable } \\
\text { neonates, survival rate, and } \\
\text { body weight. } \\
\text {-Decreased pup brain parasite } \\
\text { load. }\end{array}$ & (34) \\
\hline
\end{tabular}


attenuated virulent strains can also be used, albeit, in this case, the attenuation must be complete to ensure that the vaccine will not cause the disease (37). These vaccines present several advantages, such as using whole parasites, meaning that multiple antigens are available simultaneously. Live vaccines also do not usually require repeated immunizations or the use of adjuvants. However, a concern in using this type of vaccination is the possibility of reversing the parasite to a virulent state causing infection (36). Moreover, live vaccines are not recommended to be used in immunocompromised hosts. Toxovax ${ }^{\circledR}$, the only licensed vaccine for toxoplasmosis, administered to avoid abortion in sheep, is a live-attenuated vaccine, using the strain $\$ 48$ tachyzoites, originally isolated from an aborted lamb in New Zealand (14). This vaccine is not licensed for humans due to the possibility of parasite reversion to its virulent form (38). Moreover, it has a short shelf life and does not lead to full parasite elimination (14).

Live-attenuated vaccines may be produced by gene targeted approaches. Such is the case of a modified RH strain lacking two genes, respectively encoding micronemal protein 1 (MIC1), which associates to MICs 4 and 6 , rendering them active, and MIC3, a micronemal protein necessary for host cell invasion and MIC8 function. The double deletion of these genes ( $\Delta$ mic1-3) resulted in the loss of function of these five proteins. Female Swiss OF1 mice immunized with $\Delta$ micl-3 strain exhibited higher levels of IFN- $\gamma$ and IL-2 and a smaller number of brain cysts compared to non-immunized mice when infected with $T$. gondii. Also, all pups born from immunized animals survived compared to $64 \%$ of non-immunized mice. Moreover, $55 \%$ of the pups born from immunized mice did not present brain cysts and those with brain cysts exhibited a $91 \%$ reduction of cyst burden (30). This vaccine was also tested in Bizet, Romanov, and Solognot ewes, using the same experimental design but adapted to the ewes' pregnancy length. It showed to be effective by both subcutaneous (sc) and intraperitoneal (ip) routes, inducing protection against abortion, a higher rate of viable lambs and a decrease of brain parasite cysts in the lambs born from vaccinated ewes (31). Wang et al. attempted immunization before pregnancy with a live attenuated vaccine, using tachyzoites of the $\mathrm{RH}$ strain with a deletion of the dense granule protein 17 (GRA17) gene ( $\Delta$ gra17) that had previously shown to protect mice from lethal infection (32). The deletion entailed a defective parasitophorous vacuole (PV) and decreased intravacuolar tachyzoite proliferation, due to interference with protein transport across the PV membrane. Ip immunization with $\Delta g r a 17$ strain elicited the production of Th1type response cytokines, IL-12, and IFN- $\gamma$, as well as of IL-10 in Kunming mice (32). Thereafter, the same authors have tested this vaccine against vertical transmission using both acute and chronic infection models. No maternal clinical signs of infection and abortion were found and the litter sizes of viable neonates in immunized and RH inoculated dams were higher. In both models of infection, pups presented a higher survival rate. Maternal spleen T. gondii-induced cytokine production was evaluated at day 18 of pregnancy, 6 days after infection with Pru strain. Higher levels of Th1-type cytokines IFN- $\gamma$, IL-12, and IL-2, and of IL-10 were detected. Significantly lower parasite 
burden was found in the brain of immunized dams. Further, partial protection was observed, concerning brain parasite load in the progeny of these animals (32). Recently, a live-attenuated vaccine of the $\mathrm{RH}$ strain was engineered to harbor a deletion of Gra17 and of novel putative transporter 1 (NPT1) gene, encoding a selective arginine transporter (33). The virulence of this strain

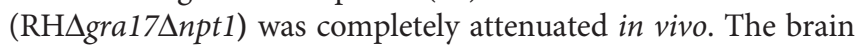
cyst burden of immunized dams was significantly lower and no abortions were observed compared with non-immunized infected mice. All pups born from immunized infected mice had about 15 times fewer brain cysts than non-immunized infected mice pups (33).

A live-attenuated vaccine using tachyzoites of the Pru strain with a deletion of the calcium-dependent protein kinase 2 (CDPK2) gene $(\Delta c d p k 2)$ was also developed by Wang et al. (34). CDPKs harbored by T. gondii are required for cell invasion and gliding motility and are important virulence factors. Specifically, CDPK2 prevents accumulation of amylopectin to toxic levels in the cell, that would cause the parasite to be morphologically defective and unable to form cysts. Therefore, these parasites were incapable of establishing chronic infection since they were not able to form tissue cysts. Dam brain cyst burden was, in average, 43 times lower than that of non-immunized challenged dams. Splenocytes from immunized dams produced higher levels of IFN- $\gamma$, IL-2, IL-12, and IL-10 compared with non-immunized mice when stimulated in vitro with soluble tachyzoite antigen. These results indicated that this vaccination approach led to a balanced pro- and counter-inflammatory maternal response, useful to control infection but also to avoid potentially harmful excessive inflammation. Pups from non-immunized infected mice harbored in average $919 \pm 339$ brain cysts, whereas only $41.4 \%$ of the pups from immunized infected mice harbored cysts, averaging $60 \pm 33$ cyst per brain (34). Recently, Wang et al. created a live-attenuated vaccine from the $T$. gondii $\mathrm{RH}$ strain with a deletion of the tyrosine kinase-like 1 (TKL1) gene (RH $\Delta t k l 1)$ (35). Vaccinated Kunming mice remained without clinical signs of infection and showed significant decrease in brain cyst burden 30 days after delivery. No abortions occurred and litter size was unaltered in immunized mice when infected, while all non-immunized infected mice suffered abortions. A decreased brain cyst load was observed in the pups from immunized infected dams indicating reduced vertical transmission (35).

\section{Recombinant Protein Vaccines}

Recombinant $T$. gondii surface antigen 1 (rSAG1) protein (39) was assessed in two models of congenital infection (Table 2). Haumont et al. immunized Dunkin-Hartley guinea pigs subcutaneously (sc) with rSAG1 three times at 3-week intervals and intradermally challenged 3 weeks after breeding (25). Vaccination induced protection against maternal-fetal transmission as assessed by the brain parasite load in the live pups. However, the SAG1-specific IgG levels in newborn pups did not correlate with protection, while cellular responses were not evaluated (25). In another study, BALB/c and CBA/J mice $\left(H 2^{d}\right.$ and $H 2^{k}$ background, respectively) were sc immunized twice with rSAG1 (40). A reduction of $50 \%$ of maternal-fetal transmission in $\mathrm{BALB} / \mathrm{c}$, but not in $\mathrm{CBA} / \mathrm{J}$ mice, was observed. Protection found in immunized $\mathrm{BALB} / \mathrm{c}$ mice correlated with a maternal increase in rSAG1-specific IgG1 and a decrease in rSAG1-specific IgG2a. IFN- $\gamma$ and IL-10 levels were increased in serum and in supernatants of T. gondii lysate antigen (TLA)stimulated splenocytes obtained from vaccinated animals. In contrast, the immunized $\mathrm{CBA} / \mathrm{J}$ mice showed no protection and significantly increased serum IL-10 and IL-4 levels. Further, no differences were observed concerning serum IFN- $\gamma$ or IFN- $\gamma$ levels in the supernatants of TLA ex-vivo stimulated spleen cells from both rSAG1-vaccinated or control CBA/J animals. These observations suggest that the Th1-/Th2type responses induced by the immunization used were affected by the host genetic background, such as the major histocompatibility complex, leading to the different outcomes after immunization (40).

\section{DNA Vaccines}

DNA vaccines are among the most promising in $T$. gondii research. These vaccines have numerous advantages such as ease of development, low-cost production, stable storage, and shipping. More than 50 vaccine variants have been experimentally produced and tested and have shown positive results in their protective capacity using exogenous infection models $(36,37)$. Vaccination with a DNA plasmid encoding SAG1, which previously showed to protect BALB/c mice against infection with the avirulent Beverly type- 2 strain, upon intra-muscular immunization with PltPASAG1 plasmid, was tested in a congenital infection model. However, maternalfetal transmission was not reduced as compared to shamimmunized control mice (41)

This observation led to the conclusion that different immune mechanisms could mediate protection in adult-acquired infection and congenital parasite transmission (41). Another approach was performed by Mevelec et al. combining DNA plasmids encoding SAG1, T. gondii dense granule antigen 4 (GRA4) and murine granulocyte-macrophage colonystimulating factor (GM-CSF) (42). The survival rates of pups from immunized infected dams was significantly higher compared to non-immunized infected dams. These results indicate that DNA plasmid multiantigen vaccine works better than a single antigen vaccine (42). Further studies are however necessary to highlight the suitability and efficacy of this type of vaccines in vertical infection.

\section{Exosome Vaccines}

Exosomes are nano-sized vesicles released by most eukaryotic cells (14). These vesicles can contain a wide variety of molecules, such as proteins, lipids, and nucleic acids, able to activate cellular and humoral responses altering the outcome of parasite infections (45). They can transfer mRNA, miRNA, and proteins between cells, representing a communication path between cells, necessary for immune homeostasis $(14,45)$. Studies showed that immunization with exosomes released from $T$. gondii-pulsed dendritic cells (DCs) induced protection against congenital toxoplasmosis, associated with IFN- $\gamma$ and IL-10 responses in 
TABLE 2 | Non-live vaccines in vertical Toxoplasma gondii infection models.

\begin{tabular}{|c|c|c|c|c|c|c|c|c|}
\hline $\begin{array}{l}\text { Strain/ } \\
\text { animal }\end{array}$ & Immunogen/delivery & $\begin{array}{c}\text { Day of } \\
\text { mating post- } \\
\text { immunization }\end{array}$ & $\begin{array}{l}\text { ChallengePregnancy } \\
\text { day/route/\#parasite } \\
\text { form/strain }\end{array}$ & Dam sacrifice & Maternal parameters & Progeny parameters & Highlighted results & References \\
\hline $\begin{array}{l}\text { Dunkin- } \\
\text { Hartley/ } \\
\text { guinea pigs* }\end{array}$ & $\begin{array}{l}\text { Recombinant SAG1/ } \\
\text { sc }\end{array}$ & Day 21 & $\begin{array}{l}21 \text { Days after mating/ } \\
\mathrm{id} / \\
5 \times 10^{5} \text { tachyzoites/ } \\
\text { C56 strain }\end{array}$ & NS & $\begin{array}{l}\text {-Specific IgG antibodies at the time } \\
\text { of delivery }\end{array}$ & $\begin{array}{l}\text {-Number of litters negative, } \\
\text { partially positive, and } \\
\text { positive. } \\
\text {-Number of stillborn and } \\
\text { viable pups and } T \text {. gondii } \\
\text { positive. } \\
\text {-Pups brain infectious status } \\
2 \text { days after birth. } \\
\text {-Specific neonate lgG } \\
\text { antibodies. }\end{array}$ & $\begin{array}{l}\text {-Protection against } \\
\text { maternal-fetal } \\
\text { transmission (66-86\%) } \\
\text {-No correlation with } \\
\text { specific lgG levels in the } \\
\text { newborn pups. }\end{array}$ & (25) \\
\hline $\begin{array}{l}\mathrm{BALB} / \mathrm{c} \text { and } \\
\mathrm{CBA} / \mathrm{J} / \mathrm{mice}\end{array}$ & $\begin{array}{l}\text { Recombinant SAG1/ } \\
\text { sc }\end{array}$ & Day 60 & $\begin{array}{l}\text { Day } 12 \text { of pregnancy/ } \\
\text { oral/ } \\
10 \text { cysts/ } \\
\text { Me } 49 \text { strain }\end{array}$ & Day 19 of pregnancy & $\begin{array}{l}\text {-Maternal SAG1 IgG1 and lgG2a } \\
\text {-Ex-vivo splenocyte specific } \\
\text { cytokine production }\end{array}$ & -Fetus parasite load & $\begin{array}{l}\text {-Protection against } \\
\text { maternal-fetal } \\
\text { transmission in BALB/C } \\
\text { mice (50\%) } \\
\text {-Increased maternal IFN- } \\
\gamma \text { and IL-10 production. } \\
\text { Higher maternal rSAG1 } \\
\text { specific IgG1 levels in } \\
\text { BALB/c mice. } \\
\text { - No protection in CBAJJ } \\
\text { mice associated with a } \\
\text { Th2 response. }\end{array}$ & $(40)$ \\
\hline BALB/c/mice & $\begin{array}{l}\text { SAG1-DNA plasmid/ } \\
\text { im }\end{array}$ & Day 14 & $\begin{array}{l}\text { Day } 12 \text { of pregnancy/ } \\
\text { oral/ } \\
10 \text { cystes/ } \\
\text { Beverley strain }\end{array}$ & NS & $\begin{array}{l}\text { Uterus examination (resorptions) or } \\
\text { still births (at delivery) }\end{array}$ & $\begin{array}{l}\text {-Survival and specific lgG in } \\
\text { pups } 12 \text { weeks after birth } \\
\text {-Number of survival pups at } \\
\text { day } 12 \text { after birth }\end{array}$ & $\begin{array}{l}\text {-No protection against } \\
\text { maternal fetal } \\
\text { transmission (no } \\
\text { differences in pups's } \\
\text { survival and specific lgG } \\
\text { levels). }\end{array}$ & $(41)$ \\
\hline $\begin{array}{l}\text { Swiss OF1/ } \\
\text { mice }\end{array}$ & $\begin{array}{l}\text { pSAG1mut+pGRA4+ } \\
\text { pGMCSF } \\
\text { DNA plasmids/ } \\
\text { im }\end{array}$ & Day 15 & $\begin{array}{l}\text { Day } 7-10 \text { of } \\
\text { pregnancy/oral/ } \\
70 \text { cysts/ } \\
76 \mathrm{~K} \text { strain }\end{array}$ & NS & NE & $\begin{array}{l}\text {-Survival (days } 1-30 \text { after } \\
\text { birth) } \\
\text { - Weight evaluation (days } 8 \text {, } \\
15 \text {, and } 30 \text { after birth). } \\
\text { - Brain cyst burden (day } 30 \\
\text { after birth) }\end{array}$ & $\begin{array}{l}\text {-Higher survival rates but } \\
\text { no differences in pups's } \\
\text { body weight. } \\
\text {-No protection against } \\
\text { parasite vertical } \\
\text { transmission (equal brain } \\
\text { cyst burden). }\end{array}$ & (42) \\
\hline CBA/J/mice & $\begin{array}{l}\text { Exosomes derived } \\
\text { from DC pulsed with } \\
T \text {. gondii total antigen } \\
\text { sc }\end{array}$ & Day 14 & $\begin{array}{l}\text { Day } 13 \text { of pregnancy/ } \\
\text { oral/ } \\
25 \text { cysts/ } \\
76 \text { K strain }\end{array}$ & 2 months after infection & Brain cyst load & $\begin{array}{l}\text {-Survival (days } 1-42 \text { after } \\
\text { birth) } \\
\text {-Weight evaluation every } 4 \\
\text { days for } 42 \text { days. } \\
\text {-Brain cyst burden (6 weeks } \\
\text { after birth) } \\
\text {-Specific lgG isotypes and } \\
\text { IgA response and ex-vivo } \\
\text { spleen and lymph node } \\
\text { specific cytokine production } \\
\text { ( } 6 \text { weeks after birth). }\end{array}$ & $\begin{array}{l}\text { - Decreased maternal } \\
\text { brain parasite load. } \\
\text { - Higher survival rate and } \\
\text { pups body weight. } \\
\text { - IgG2a, lgG2b, IL-2, } \\
\text { IFN- } \gamma \text {, IL-4, and IL-10 } \\
\text { responses in the pups. } \\
\text { - Decreased pup brain } \\
\text { parasite load. }\end{array}$ & (43) \\
\hline
\end{tabular}




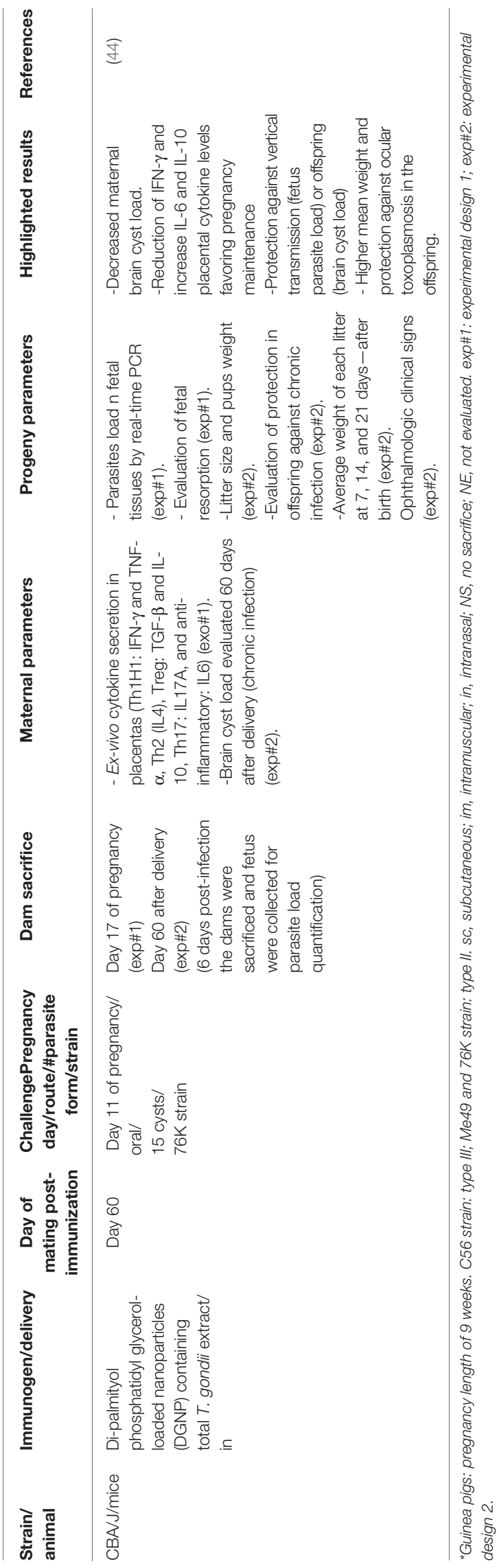

the pups (43). This vaccine, when administered before pregnancy, provided strong fetus protection against infection. Low cyst burden was observed in both immunized dams and pups delivered from immunized dams (43). This was the first description, so far, studying immune responses in the offspring from vaccinated females.

\section{Nanoparticle-Based Vaccines}

Advances in research have revealed the use of nanoparticles (NP) as antigen delivery systems, thus setting the basis for a new type of vaccines. This antigen delivery system avoids antigen degradation and increases bloodstream life span, internalization, and presentation by antigen-presenting cells, such as DCs (14). Dipalmitoyl phosphatidyl glycerol-loaded nanoparticles (DGNP) loaded with $T$. gondii total antigen extract were shown to deliver parasitic antigens to mucosa after intranasal immunization, inducing a specific Th1/Th17 response in vivo (46). Further work has tested the safety and efficiency of DGNP in congenital toxoplasmosis (44). Placental levels of cytokine production were analyzed, which revealed no signs of inflammation exacerbation in immunized mice, even though, there was an increase in IFN- $\gamma$ concentration. IL-10 and IL-6 levels were significantly raised. Survival of offspring and dams was $100 \%$ and mean litter size and pup weight was not diminished in infected immunized mice. The parasite burden on the fetus was $86 \%$ reduced from females immunized with DGNT/TE compared to controls (44).

\section{CONCLUSION}

Most of the research work that addresses vaccination using vertical $T$. gondii infection models assessed the immune response to vaccination, determining the $\operatorname{IgG}$ isotypes and cytokines produced in response to parasite antigen stimulation. Typically, production of IFN- $\gamma$, IL-2, IL-12, IL-10, and, occasionally, IL-4 was found elevated in response to vaccination in non-pregnant mice until 60-70 days postvaccination. This might explain why this time-point has been referred in the achievement of pregnant animals, since the balance between these cytokines is essential in successful pregnancy as reported in almost all the studies referred here.

Most reports gather data from acute, chronic, and congenital infection experiments. However, the immune status during pregnancy is altered (7), therefore, the data from non-pregnant mice must be carefully discussed and not directly extrapolated to pregnancy due its specific immune status.

In two studies using live attenuated vaccines, mixed maternal Th1-/Th2-type responses were induced, being discussed as Th1 crucial against $T$. gondii congenital infection and Th2 essential for pregnancy maintenance $(32,34)$. Currently, a balance between several subsets of T cells must be considered such as Th1, Th2, Th9, Th17, Th22, and follicular Th cells (Tfh) for a successful human pregnancy (47). Indeed, these $\mathrm{T}$ cell subsets contribute to the immune response occurring at the maternal-fetal interface, known to be important not only in protecting against infection and controlling inflammatory response, but also contributing to 
immune homeostasis, implantation, decidualization, maternal immune tolerance and acceptance of the fetus, and parturition (47).

A heterogeneity in the experimental designs was found in the studies reported. The difficulty of performing research work with congenital infection models is very high and may explain the scarcity of research in this area. It would be useful to choose a standard experimental design in the study of vaccines, using congenital models able to get valid and robust results. Murine models are the most chosen because they offer simplified logistics, including the facility to monitor physiologic parameters and the short length of pregnancy. Further, mice allow experiments with higher animal numbers, availability of immunological reagents and genetically modified hosts. Mice were largely validated as an adequate model to study congenital toxoplasmosis, by reproducing many features of human infection (21).

None of the vaccines described so far managed to fully protect against T. gondii vertical transmission, even if providing multiantigenic stimulus. The lack of more effective vaccination approaches may be a consequence of the scarce knowledge on the host protective immune molecular and cellular mechanisms operating at the maternal-fetal interface, specifically at decidua and placenta. Indeed, only one work testing nanoparticles containing $T$. gondii total extracts, analyzed the cytokine profile in placentas from vaccinated dams (44). This study found that a reduction in IFN- $\gamma$ and an increase in IL- 6 and IL-10 production was associated with protection against vertical transmission and ocular toxoplasmosis in the offspring (44). Determining the type of immune response at maternal-fetal interface that can correlate with protection will be useful to refine vaccination approaches, by selecting adjuvants that could

\section{REFERENCES}

1. Torgerson PR, Devleesschauwer B, Praet N, Speybroeck N, Willingham AL, Kasuga F, et al. World Health Organization Estimates of the Global and Regional Disease Burden of 11 Foodborne Parasitic Diseases, 2010: A Data Synthesis. PLoS Med (2015) 12(12):e1001920. doi: 10.1371/journal. pmed.1001920

2. Torgerson PR, Mastroiacovo P. The global burden of congenital toxoplasmosis: a systematic review. Bull World Health Organ (2013) 91 (7):501-8. doi: 10.2471/blt.12.111732

3. Nayeri T, Sarvi S, Moosazadeh M, Amouei A, Hosseininejad Z, Daryani A. The global seroprevalence of anti-Toxoplasma gondii antibodies in women who had spontaneous abortion: A systematic review and meta-analysis. PLoS Negl Trop Dis (2020) 14(3):e0008103. doi: 10.1371/journal.pntd.0008103

4. Pittman KJ, Knoll LJ. Long-Term Relationships: the Complicated Interplay between the Host and the Developmental Stages of Toxoplasma gondii during Acute and Chronic Infections. Microbiol Mol Biol Rev (2015) 79(4):387-401. doi: 10.1128/mmbr.00027-15

5. McAuley JB. Congenital Toxoplasmosis. J Pediatr Infect Dis Soc (2014) 3 Suppl 1(Suppl 1):S30-5. doi: 10.1093/jpids/piu077

6. Elbez-Rubinstein A, Ajzenberg D, Darde ML, Cohen R, Dumetre A, Yera H, et al. Congenital toxoplasmosis and reinfection during pregnancy: case report, strain characterization, experimental model of reinfection, and review. J Infect Dis (2009) 199(2):280-5. doi: 10.1086/595793

7. Borges M, Magalhaes Silva T, Brito C, Teixeira N, Roberts CW. How does toxoplasmosis affect the maternal-foetal immune interface and pregnancy? Parasite Immunol (2019) 41(3):e12606. doi: 10.1111/pim.12606 adequately polarize $\mathrm{T}$ cell responses, thereby leading to protection against congenital infection. On the other hand, it would be also important to understand the immune response developed in the pups born from vaccinated dams and infected during pregnancy. To our knowledge, only one study analyzed the immune response in surviving pups born from vaccinated dams, having found a mixed Th1- and Th2-type response associated with a high survival rate, high weight mean, and low cyst brain burden (43). The development of adaptive fetal immune responses are observed in neonates exposed to an infection environment in uterus but not necessarily infected themselves (48). Thus, it will be worthy to get new insights into how $\mathrm{T}$ cell responses and related mediators operate in fetuses and in neonates. Novel vaccine design formulations and delivery systems can also be improved, concerning parasite antigen determinants and elicited immune mechanisms involved in protection against T. gondii vertical infection (36).

\section{AUTHOR CONTRIBUTIONS}

$\mathrm{MBa}, \mathrm{DT}$, and MBo wrote the initial manuscript. All authors contributed to the article and approved the submitted version.

\section{FUNDING}

This work was supported by the Applied Molecular Biosciences Unit-UCIBIO, which is financed by national funds from FCT (UIDP/04378/2020 and UIDB/04378/2020). AC was supported by FCT Individual CEEC 2017 Assistant Researcher Grant 352 CEECIND/01514/2017.

8. Flegr J, Escudero DQ. Impaired health status and increased incidence of diseases in Toxoplasma-seropositive subjects - an explorative cross-sectional study. Parasitology (2016) 143(14):1974-89. doi: 10.1017/s0031182016001785

9. Sutterland AL, Fond G, Kuin A, Koeter MW, Lutter R, van Gool T, et al. Beyond the association. Toxoplasma gondii in schizophrenia, bipolar disorder, and addiction: systematic review and meta-analysis. Acta Psychiatr Scand (2015) 132(3):161-79. doi: 10.1111/acps.12423

10. Sasai M, Pradipta A, Yamamoto M. Host immune responses to Toxoplasma gondii. Int Immunol (2018) 30(3):113-9. doi: 10.1093/intimm/dxy004

11. Moroda M, Takamoto M, Iwakura Y, Nakayama J, Aosai F. Interleukin-17ADeficient Mice Are Highly Susceptible to Toxoplasma gondii Infection Due to Excessively Induced T. gondii HSP70 and Interferon Gamma Production. Infect Immun (2017) 85(12):e00399-17. doi: 10.1128/iai.00399-17

12. Melchor SJ, Ewald SE. Disease Tolerance in Toxoplasma Infection. Front Cell Infect Microbiol (2019) 9:185. doi: 10.3389/fcimb.2019.00185

13. Sasai M, Yamamoto M. Innate, adaptive, and cell-autonomous immunity against Toxoplasma gondii infection. Exp Mol Med (2019) 51(12):1-10. doi: 10.1038/s12276-019-0353-9

14. Wang JL, Zhang NZ, Li TT, He JJ, Elsheikha HM, Zhu XQ. Advances in the Development of Anti-Toxoplasma gondii Vaccines: Challenges, Opportunities, and Perspectives. Trends Parasitol (2019) 35(3):239-53. doi: 10.1016/j.pt.2019.01.005

15. Innes EA, Hamilton C, Garcia JL, Chryssafidis A, Smith D. A one health approach to vaccines against Toxoplasma gondii. Food Waterborne Parasitol (2019) 15:e00053. doi: 10.1016/j.fawpar.2019.e00053

16. Munoz M, Liesenfeld O, Heimesaat MM. Immunology of Toxoplasma gondii. Immunol Rev (2011) 240(1):269-85. doi: 10.1111/j.1600-065X.2010.00992.x 
17. Brito C, MS T, MC M, Wyrwas W, Oliveira B, MF B, et al. Toxoplasma gondii infection reduces serum progesterone levels and adverse effects at the maternal-foetal interface. Parasite Immunol (2020) 42(2):e12690. doi: $10.1111 /$ pim. 12690

18. Dunay IR, Gajurel K, Dhakal R, Liesenfeld O, Montoya JG. Treatment of Toxoplasmosis: Historical Perspective, Animal Models, and Current Clinical Practice. Clin Microbiol Rev (2018) 31(4):e00057-17. doi: 10.1128/ cmr.00057-17

19. Fisch D, Clough B, Frickel EM. Human immunity to Toxoplasma gondii. PLoS Pathog (2019) 15(12):e1008097. doi: 10.1371/journal.ppat.1008097

20. Suzuki Y, Yang Q, Remington JS. Genetic resistance against acute toxoplasmosis depends on the strain of Toxoplasma gondii. J Parasitol (1995) 81(6):1032-4. doi: 10.2307/3284069

21. Roberts CW, Brewer JM, Alexander J. Congenital toxoplasmosis in the Balb/c mouse: prevention of vertical disease transmission and fetal death by vaccination. Vaccine (1994) 12(15):1389-94. doi: 10.1016/0264-410X(94)90147-3

22. Menzies FM, Henriquez FL, Roberts CW. Immunological control of congenital toxoplasmosis in the murine model. Immunol Lett (2008) 115 (2):83-9. doi: 10.1016/j.imlet.2007.10.009

23. Coutinho LB, Gomes AO, Araújo EC, Barenco PV, Santos JL, Caixeta DR, et al. The impaired pregnancy outcome in murine congenital toxoplasmosis is associated with a pro-inflammatory immune response, but not correlated with decidual inducible nitric oxide synthase expression. Int J Parasitol (2012) 42 (4):341-52. doi: 10.1016/j.ijpara.2012.01.006

24. Dos Santos TR, Faria GD, Guerreiro BM, Dal Pietro NH, Lopes WD, da Silva $\mathrm{HM}$, et al. Congenital Toxoplasmosis in Chronically Infected and Subsequently Challenged Ewes. PLoS One (2016) 11(10):e0165124. doi: 10.1371/journal.pone.0165124

25. Haumont M, Delhaye L, Garcia L, Jurado M, Mazzu P, Daminet V, et al. Protective immunity against congenital toxoplasmosis with recombinant SAG1 protein in a guinea pig model. Infect Immun (2000) 68(9):4948-53. doi: 10.1128/iai.68.9.4948-4953.2000

26. Freyre A, Falcón J, Méndez J, González M. Toxoplasma gondii: an improved rat model of congenital infection. Exp Parasitol (2008) 120(2):142-6. doi: 10.1016/j.exppara.2008.06.007

27. Freyre A, Falcón J, Méndez J, Rodriguez A, Correa L, Gonzalez M. Toxoplasma gondii: Partial cross-protection among several strains of the parasite against congenital transmission in a rat model. Exp Parasitol (2006) 112(1):8-12. doi: 10.1016/j.exppara.2005.08.009

28. Freyre A, Araujo FA, Fialho CG, Bigatti LE, Falcón JD. Protection in a hamster model of congenital toxoplasmosis. Vet Parasitol (2012) 183(3-4):359-63. doi: 10.1016/j.vetpar.2011.07.039

29. Fonseca BM, Correia-da-Silva G, Teixeira NA. The rat as an animal model for fetoplacental development: a reappraisal of the post-implantation period. Reprod Biol (2012) 12(2):97-118. doi: 10.1016/s1642-431x(12)60080-1

30. Ismael AB, Dimier-Poisson I, Lebrun M, Dubremetz JF, Bout D, Mevelec MN. Mic1-3 knockout of Toxoplasma gondii is a successful vaccine against chronic and congenital toxoplasmosis in mice. J Infect Dis (2006) 194(8):1176-83. doi: $10.1086 / 507706$

31. Mevelec MN, Ducournau C, Bassuny Ismael A, Olivier M, Seche E, Lebrun M, et al. Mic1-3 Knockout Toxoplasma gondii is a good candidate for a vaccine against T. gondii-induced abortion in sheep. Vet Res (2010) 41(4):49. doi: 10.1051/vetres/2010021

32. Wang JL, Elsheikha HM, Zhu WN, Chen K, Li TT, Yue DM, et al. Immunization with Toxoplasma gondii GRA17 Deletion Mutant Induces Partial Protection and Survival in Challenged Mice. Front Immunol (2017) 8:730. doi: 10.3389/fimmu.2017.00730

33. Liang QL, Sun LX, Elsheikha HM, Cao XZ, Nie LB, Li TT, et al. RHDeltagra17Deltanpt1 Strain of Toxoplasma gondii Elicits Protective Immunity Against Acute, Chronic and Congenital Toxoplasmosis in Mice. Microorganisms (2020) 8(3):352. doi: 10.3390/microorganisms 8030352

34. Wang JL, Li TT, Elsheikha HM, Chen K, Cong W, Yang WB, et al. Live Attenuated Pru:Deltacdpk2 Strain of Toxoplasma gondii Protects Against Acute, Chronic, and Congenital Toxoplasmosis. J Infect Dis (2018) 218 (5):768-77. doi: 10.1093/infdis/jiy211
35. Wang JL, Liang QL, Li TT, He JJ, Bai MJ, Cao XZ, et al. Toxoplasma gondii tkl1 Deletion Mutant Is a Promising Vaccine against Acute, Chronic, and Congenital Toxoplasmosis in Mice. J Immunol (Baltimore Md 1950) (2020) 204(6):1562-70. doi: 10.4049/jimmunol.1900410

36. Loh FK, Nathan S, Chow SC, Fang CM. Vaccination challenges and strategies against long-lived Toxoplasma gondii. Vaccine (2019) 37(30):3989-4000. doi: 10.1016/j.vaccine.2019.05.083

37. Li Y, Zhou H. Moving towards improved vaccines for Toxoplasma gondii. Expert Opin Biol Ther (2018) 18(3):273-80. doi: 10.1080/14712598.2018. 1413086

38. Zhang NZ, Chen J, Wang M, Petersen E, Zhu XQ. Vaccines against Toxoplasma gondii: new developments and perspectives. Expert Rev Vaccines (2013) 12(11):1287-99. doi: 10.1586/14760584.2013.844652

39. Biemans R, Grégoire D, Haumont M, Bosseloir A, Garcia L, Jacquet A, et al. The conformation of purified Toxoplasma gondii SAG1 antigen, secreted from engineered Pichia pastoris, is adequate for serorecognition and cell proliferation. J Biotechnol (1998) 66(2):137-46. doi: 10.1016/S0168-1656(98) 00143-6

40. Letscher-Bru V, Pfaff AW, Abou-Bacar A, Filisetti D, Antoni E, Villard O, et al. Vaccination with Toxoplasma gondii SAG-1 protein is protective against congenital toxoplasmosis in $\mathrm{BALB} / \mathrm{c}$ mice but not in $\mathrm{CBA} / \mathrm{J}$ mice. Infect Immun (2003) 71(11):6615-9. doi: 10.1128/iai.71.11.6615-6619.2003

41. Couper KN, Nielsen HV, Petersen E, Roberts F, Roberts CW, Alexander J. DNA vaccination with the immunodominant tachyzoite surface antigen (SAG-1) protects against adult acquired Toxoplasma gondii infection but does not prevent maternofoetal transmission. Vaccine (2003) 21(21):2813-20. doi: 10.1016/S0264-410X(03)00163-4

42. Mevelec MN, Bout D, Desolme B, Marchand H, Magne R, Bruneel O, et al. Evaluation of protective effect of DNA vaccination with genes encoding antigens GRA4 and SAG1 associated with GM-CSF plasmid, against acute, chronical and congenital toxoplasmosis in mice. Vaccine (2005) 23(36):448999. doi: 10.1016/j.vaccine.2005.04.025

43. Beauvillain C, Juste MO, Dion S, Pierre J, Dimier-Poisson I. Exosomes are an effective vaccine against congenital toxoplasmosis in mice. Vaccine (2009) 27 (11):1750-7. doi: 10.1016/j.vaccine.2009.01.022

44. Ducournau C, Nguyen TT, Carpentier R, Lantier I, Germon S, Precausta F, et al. Synthetic parasites: a successful mucosal nanoparticle vaccine against Toxoplasma congenital infection in mice. Future Microbiol (2017) 12:393405. doi: $10.2217 / \mathrm{fmb}-2016-0146$

45. Coakley G, Maizels RM, Buck AH. Exosomes and Other Extracellular Vesicles: The New Communicators in Parasite Infections. Trends Parasitol (2015) 31(10):477-89. doi: 10.1016/j.pt.2015.06.009

46. Dimier-Poisson I, Carpentier R, N’Guyen TT, Dahmani F, Ducournau C, Betbeder D. Porous nanoparticles as delivery system of complex antigens for an effective vaccine against acute and chronic Toxoplasma gondii infection. Biomaterials (2015) 50:164-75. doi: 10.1016/j.biomaterials.2015.01.056

47. Wang W, Sung N, Gilman-Sachs A, Kwak-Kim J. T Helper (Th) Cell Profiles in Pregnancy and Recurrent Pregnancy Losses: Th1/Th2/Th9/Th17/Th22/Tfh Cells. Front Immunol (2020) 11:2025. doi: 10.3389/fimmu.2020.02025

48. Dauby N, Goetghebuer T, Kollmann TR, Levy J, Marchant A. Uninfected but not unaffected: chronic maternal infections during pregnancy, fetal immunity, and susceptibility to postnatal infections. Lancet Infect Dis (2012) 12(4):33040. doi: 10.1016/s1473-3099(11)70341-3

Conflict of Interest: The authors declare that the revision work was conducted in the absence of any commercial or financial relationships that could be construed as a potential conflict of interest.

Copyright (c) 2021 Barros, Teixeira, Vilanova, Correia, Teixeira and Borges. This is an open-access article distributed under the terms of the Creative Commons Attribution License (CC BY). The use, distribution or reproduction in other forums is permitted, provided the original author(s) and the copyright owner(s) are credited and that the original publication in this journal is cited, in accordance with accepted academic practice. No use, distribution or reproduction is permitted which does not comply with these terms. 